\title{
Effects of Folic Acid Consumption on Newborn Defects and Miscar- riage, and Content Uniformity Analysis of Three Different Brands of Folic Acid Tablets Dosage Forms
}

\author{
Adel B,. Mohamed ${ }^{1 *}$,Azza M,. Ali ${ }^{2}$, Samia A,. Magid ${ }^{2}$ \\ ${ }^{1}$ Department of Pathology, faculty of Veterinary Medicine, Omar Al-Mukhtar University. Al-Bayda. \\ Libya \\ ${ }^{2}$ Department of Pharmaceutics and industrial pharmacy, faculty of pharmacy, Omar Al-Mukhtar \\ University. Al-Bayda. Libya
}

Received: 04 May 2019/ Accepted: 30 December 2019

Doi: https://doi.org/10.54172/mjsc.v34i4.147

\begin{abstract}
There is a recent rise in the number of birth defects. This could be related to folic acid deficiency. Folic acid, as an antioxidant, is an important factor in preventing birth defects during embryonic development. This study, via content uniformity measurements and medical history, aimed to investigate the role of folic acid before and during pregnancy and to measure the content uniformity of different brands of folic acid tablets. The statistical study aimed to determine the relationship between folic acid consumption, miscarriage, and anomalies in newborn babies. The study studied a sample of 300 women based on their medical records. There was no significant effect ( $\mathrm{p}$ value $=0.143$ ) of folic acid consumption on the frequency of anomalies. On the other hand, there was a high significant relation $(p$-value $=0.003)$ between folic acid consumption and miscarriage. The correlation, principally with miscarriage, coincides with previous studies and highlights the importance of folic acid supplementation before and during gestation. Content uniformity measurements were made on three famous folic acid brands (Folic Acid-Nile, Folicum-Julphar and Wockhardt-UK) available at local pharmacies. Measurements on the three folic acid brands were conducted in compliance with the British Pharmacopoeia (BP) (2010) test for content uniformity. Ten tablets from each brand were tested using the UV spectrophotometric method. The results showed that only the first brand name passed the content uniformity test, while the other two brands did not comply with the standards. This result highlights the problem of under-dosing in commercially available folic acid dosage forms, and identifies the need for taking action towards the implementation of quality control on all medical drugs.
\end{abstract}

Keywords: Folic acid; Anti-oxidant; Newborn defects; Miscarriage

\section{INTRODUCTION}

Folic acid, also known as pteroyl-L-glutamic acid or N-[4-[[(2-amino-1,4-dihydro-4-oxo-6pteridinyl) methyl] amino] benzoyl]-Lglutamic acid, is a member of the B vitamin group (Matias et al., 2014). Folic acid is the synthetic form of folate and is found in different kinds of fortified foods (Ribeiro et al., 2016). As a vitamin, folic acid is not produced by natural metabolism; it is obtained from the diet. Most dietary folic acid loses its bioavailability during cooking and food processing. Yet folic acid is often recommended as a supplement when the amount of dietary folate is not sufficient (Matias et al., 2014).

Natural folate exists in the form of polyglutamates which can be hydrolyzed to monoglutamates by the action of intestinal enzymes in the jejunum. In intestinal villi, folic acid is reduced by NADPH reductase to tetrahydrofolic acid

*Corresponding Author: Adel. Mohamed . adel.mohamed@omu.edu.ly Department of Pathology, faculty of Vet. Medicine, Omar AlMukhtar University. Al-Bayda. Libya. 
(THFA). THFA then undergoes methylation to form N5 methyl THFA, which then binds to plasma proteins. THFA is vital in several metabolic pathways for nucleic acid synthesis, functioning as a donor of chemical groups with one carbon atom. Disturbances in folate and 1 Carbone metabolism have been linked with a group of congenital disorders known as NeuralTube Defects (NTDs) (Pulikkunnel \& Thomas, 2005).

Folic acid has antioxidant properties that may prevent or reduce defects and congenital abnormalities in the neural tube and the heart. NTD and heart defects are congenital abnormalities that occur at an early stage of pregnancy. Unfortunately, almost 5\% of newborn babies are born with serious congenital anomalies that tend to be permanent, and in some cases, are associated with little chance of recovery after birth (Andres et al., 2008). The only effective strategy for the prevention of these disorders is periconceptional treatment with folic acid in sufficient doses (Czeizel et al., 2013). Oral administration of folic acid prior to and during the early first trimester of pregnancy plays an important role in preventing NTDs and congenital anomalies in the heart, urinary tract, oral cavity and limbs (Bower \& Stanley, 1989; Goh et al., 2006). Sufficient levels of folate in the blood serum are associated with a reduction in NTD (Green, 2002).

Additionally, a high risk of giving birth to children with NTDs is associated with women with type I diabetes, with epilepsy or who are under carbamazepine or antifolate medication (French et al., 2003; Wald et al., 2001).

First (Hibbard, 1965), reported the relationship between deficiency of folic acid and NTDs. He noticed that women with a history of fetal anomalies had a high incidence of abnormal folate metabolism. Later, Smithells and colleagues noticed low levels of folate in the red blood cells of women who had a fetus with an NTD in comparison to control mothers
(Smithells et al., 1976). This finding led to investigations of the probability of preventing NTDs by the administration of folate supplements prior to planning for pregnancy (Smithells et al., 1980).

For the sake of reducing the risk of NTDs, supplementation of folic acid has been recommended before and during the first three months of pregnancy (McStay et al., 2017). The recommended daily dose of folic acid depends on the patient's history of birth abnormalities; the recommended preventative daily allowance of folic acid for women with no prior history of birth defects dose is $4.0 \mathrm{mg}$ per day starting at least 30 days before conception and continuing throughout the first trimester of pregnancy (Al-Mashhadane et al., 2018).

Folic acid is a water-soluble substance so that any excess is excreted with the urine (Ahn et al., 2004; Brown et al., 1997). A 4.0 to $10 \mathrm{mg}$ daily supplement of folic acid is not known to cause any toxicity to the mother or the fetus during the pregnancy. Green and colleagues stated that folic acid is not toxic but that it may mask pernicious anemia if consumed in high doses (Green, 2002).

Quality measurements of dietary folic acid are not applied worldwide, giving rise to the possibility of products with insufficient amounts of the active component (Đuriš et al., 2017). Over the years, several methods have been developed for the quantification of folic acid in pharmaceutical formulations. The present study seeks to investigate whether oral folic acid supplements commercially available in the Libyan market meet the criteria of the (Pharmacopoeia, 2010) using UV spectrophotometry for the quantification of folic acid in pharmaceutical formulations.

This study aims to investigate any prospective relation between folic acid consumption and pregnancy anomalies or miscarriage. Furthermore, the study aimed to run content uniformi- 
ty measurement of three different common brands of folic acid tablets dosage form to check whether these brands contain the actual percentage of folic acid assigned on (Pharmacopoeia, 2010).

\section{MATERIALS AND METHODS}

Collection of data for the correlation between folic acid consumption and anomalies and miscarriage: To study the relationship between folic acid consumption and birth anomalies and miscarriage, 300 tested women were selected randomly for the assessment based on a written questioner and medical history at maternity centers. The assessment focused on evaluating the number of miscarriage and anomalies cases in relation to the consumption of folic acid before and during pregnancy.
Statistical analysis was performed by The $\mathrm{R}$ Project for Statistical Computing. $p$-values were calculated based on Fisher's Exact Test for Count Data.

For quality control measurements, samples of three commercial brands of $5 \mathrm{mg}$ folic acid tablets were purchased from several private pharmacies in Al-Bayda, Libya as shown in Table 1. All samples were assessed within their valid shelf-life. Folic acid standard (Alfa Aesar, United Kingdom, Lot No J1791A) was obtained from the central store of the University of Omar Al-Mukhtar, Al-Bayda, Libya. For the preparation of the solutions of the standards and tested samples, distilled water and highgrade glassware were used throughout the work.

Table:(1). Folic acid 5mg tablets evaluated in the study

\begin{tabular}{llllll}
\hline \hline Brand & Brand name & Manufacture Date & Expiry Date & Batch No & Manufacturer \\
\hline A & Folicum & $04 / 2013$ & $07 / 2018$ & 0009 & Julphar,UAE \\
B & Folic acid & $10 / 2015$ & $10 / 2018$ & T651516 & Nile, Egypt \\
C & Folic acid & $04 / 2017$ & $03 / 2020$ & 532823 & Wockhardt,UK \\
\hline \hline
\end{tabular}

Ultraviolet Spectrophotometry: Ultraviolet (UV) measurements were made on GENESYS 10S UV-Vis spectrophotometer (Thermo Fisher Scientific, USA) with $1 \mathrm{~cm}$ optical path. Quartz cells were used to measure absorbance of all the solutions.

\section{Preparation of Standard Stock Solution:}

Standard Stock Solution of Folic Acid: An accurately weighed quantity of folic acid (10 $\mathrm{mg}$ ) was transferred into a $100 \mathrm{ml}$ volumetric flask. This small quantity of drug was dissolved in distilled water and shaken manually for $10 \mathrm{~min}$ and diluted up to the mark with distilled water to give a stock solution (100 $\mu \mathrm{g} / \mathrm{ml}$ ). BP. Vol.1. (2009).

Working standard solution of Folic Acid: An aliquot $(0.1 \mathrm{ml})$ from a standard stock solution
$(100 \mu \mathrm{g} / \mathrm{ml})$ was transferred to a $10 \mathrm{ml}$ volumetric flask and diluted to the mark with distilled water to obtain a working standard solution

(1 $\mu \mathrm{g} / \mathrm{ml}$ ) of folic acid. The solution was scanned by UV-Visible spectrophotometer within the range $200-300 \mathrm{~nm}$ using water as a blank.

Preparation of Calibration Curve: From the standard stock solution of folic acid (100 $\mu \mathrm{g} / \mathrm{ml}) 1,3,5,6,7$, or $8 \mathrm{ml}$ of solution were pipetted out into a series of $100 \mathrm{ml}$ volumetric flasks. The volume in each flask was made up to $100 \mathrm{ml}$ with distilled water to obtain concentrations of $1,3,5,6,7$, and $8 \mu \mathrm{g} / \mathrm{ml}$ folic acid. The absorbance of the above solutions was measured at a maximum absorbance $(\lambda \max )$. The calibration curve was constructed by plotting absorbance vs. concentration. Line- 
arity and a regression equation were also calculated. Each response shown was the average of three determinations.

\section{Estimation of Three Marketed Formula-} tions: 10 tablets from each brand were chosen randomly and assayed individually: the tablets were weighed and powdered using a porcelain mortar and pestle. An amount of the powder equivalent to $0.05 \mathrm{~g}$ of tablet was dissolved in $100 \mathrm{ml}$ of distilled water in a volumetric flask and shaken for 10 minutes. The solution was filtered through Whatman filter paper no. 54. $20 \mathrm{ml}$ of the above filtrate was diluted to 100 $\mathrm{ml}$ with distilled water and the absorbance was measured at $\lambda \max$. The average amount of drug per tablet present in each batch was calculated with the help of an appropriate calibration curve constructed from the absorbance values of folic acid.

A selection of an absorbance wavelength for folic acid $(\lambda \max )$ was calculated by scanning the standard solution of folic acid between 200 $300 \mathrm{~nm}$. An absorbance maximum was obtained at $287 \mathrm{~nm}$.

\section{RESULT AND DISCUSSION}

Statistical analysis showed a non-significant relation $(p$-value $=0.143$ ) between folic acid consumption and anomalies in Figure.1. Among women who were taking folic acid during pregnancy, 166 had no anomalies while 13 had one anomaly. Data also showed that women who took folic acid in both before and during pregnancy had reduced the risk of having babies with birth defects than those who had never taken folic acid. For the remaining 121 cases, the study result showed a weak relation between folic acid consumption and anomalies.

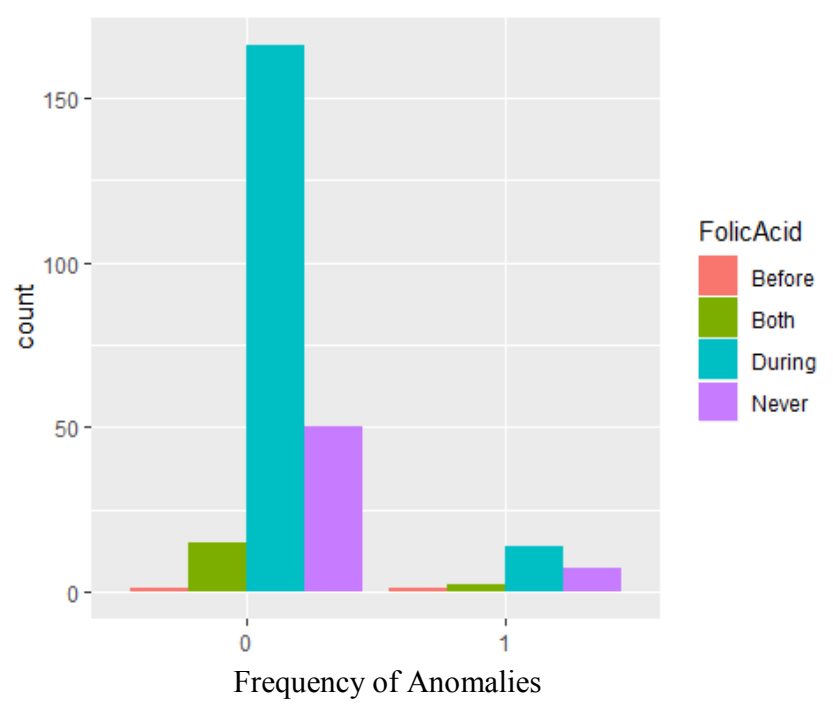

Figure:(1). Comparison between folic intakes before and during pregnancy and the frequency of anomalies.

Figure. 2 showed a significant relationship ( $p$ value $=0.0039$ ) between folic acid consumption and miscarriage. Among women who were under folic acid medication during their pregnancies, the majority (124) did not experience a miscarriage. However, the frequency of miscarriage rises to 1 and 2 for many of those who never took folic acid during their pregnancies.

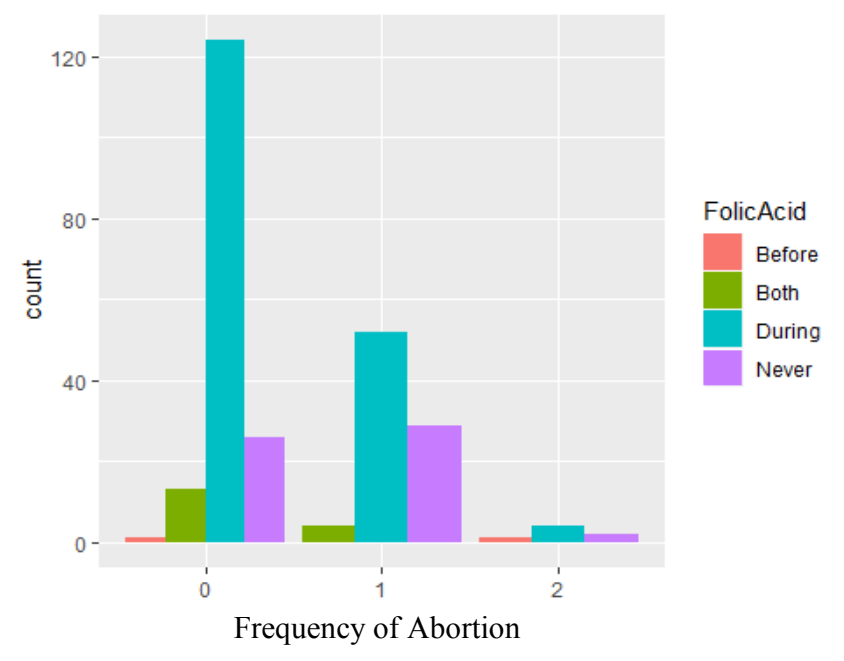

Figure: (2). Comparison between folic acid intakes before and during pregnancy and the frequency of miscarriage (abortion).

Although many previous studies showed a strong relationship between folic acid intake during pregnancy and the absence of anomalies 
in newborn babies, it was not the case in this study. This might be attributed to the power of the sample or the presence of a bias during the sampling that might not represent the population. Lack of awareness campaigns of the importance of folic acid before and during pregnancy might be the main reason behind the increase in birth defects. $5 \mathrm{mg}$ is the recommended daily dose of folic acid for maintaining pregnancy. Folic acid is available at local pharmacies under different brand names, most of which were imported without quality measurements. Folic acid is also available in $500 \mathrm{mcg}$ doses, which is recommended at least for 3 months before planning pregnancies. Sometimes, due to human error, lower doses $(500 \mathrm{mcg})$ replace the recommended dose $(5 \mathrm{mg})$ during pregnancy, which eventually affects the integrity of folic acid during important periods in embryonic development. It is worth mentioning that there are many different factors such as genetic, environmental, infection and nutrition that are associated with increasing the rate of birth anomalies and miscarriage thus these factors might interfere with the lack of folic acid consumption during pregnancy.

The content uniformity measurement for three of the most frequently consumed folic acid brands in the local pharmacies: The linearity range of folic acid absorbance detection was found to be between $1-8 \mu \mathrm{g} / \mathrm{ml}$ as shown in Figure. 3. The correlation coefficient and regression line equation of folic acid at $287 \mathrm{~nm}$ are shown in table 2.
Table: (2). Correlation coefficient and regression line equation for calibration curve for folic acid. $(n=6)$.

\begin{tabular}{ccc}
\hline \hline Wavelength & $\begin{array}{c}\text { Correlation } \\
\text { co-efficient }\left(\mathrm{R}^{2}\right)\end{array}$ & $\begin{array}{c}\text { Regression line } \\
\text { equation }\end{array}$ \\
\hline \multirow{2}{*}{$287 \mathrm{~nm}$} & 0.998 & $\mathrm{y}=0.049 \mathrm{x}+$ \\
& 0.008 \\
\hline \hline
\end{tabular}

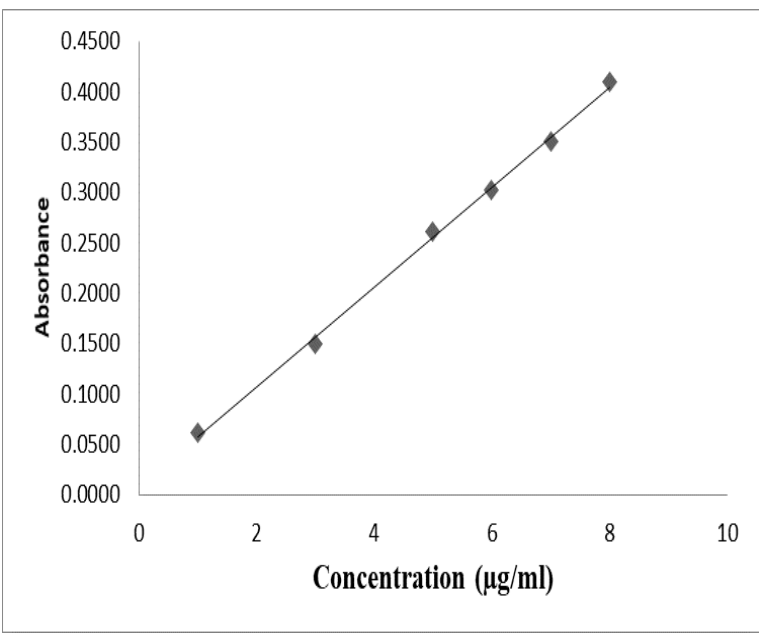

Figure: (3). Linearity Spectra of Folic Acid.

The results obtained from the estimation of 3 different brands (A, B, and $\mathrm{C}$ ) of folic acid available in local pharmacies in Al-Bayda show that the percentage of drug content of brand $\mathrm{B}$ tablets as shown in Table 3 is within the limit $(85 \%$ and not more than $115 \%$ of the labeled drug). This means that this brand complies with the British pharmacopoeia guideline of the content uniformity test.

Table:(3). The average weight, amount of drug, and percentage of drug content for each tablet of brand B.

\begin{tabular}{|c|c|c|c|c|c|c|c|c|c|c|}
\hline Tablet no & 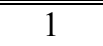 & 2 & 3 & 4 & 5 & 6 & 7 & 8 & 9 & 10 \\
\hline $\begin{array}{l}\text { Average weight of each tablet } \\
(\mathrm{mg})\end{array}$ & 129.2 & 128.3 & 142.5 & 128.6 & 132.1 & 131.5 & 131.8 & 128.7 & 136.5 & 129.5 \\
\hline $\begin{array}{l}\text { Amount of drug in each tab- } \\
\text { let(mg) }\end{array}$ & 5.2 & 4.9 & 5.9 & 5.4 & 4.7 & 4.9 & 5.2 & 5.1 & 5.4 & 5.2 \\
\hline$\%$ of content & 104 & 98 & 118 & 108 & 94 & 99 & 104 & 102 & 109 & 104 \\
\hline
\end{tabular}


The percentage of drug content of brand A and $\mathrm{C}$ tablets, as shown in Tables 4 and 5, respectively, is below the lower limit ( $85 \%$ of the labeled drug). This means that these brands are not compliant with the British pharmacopeia content uniformity test. No previous similar studies have been found, which investigated the content uniformity of these tested brands of folic acid. However, if there was any similar study, it would consider important factors such as brand name and batch number which might affect the final decision.

Table: (4). The average weight, amount of drug, and percentage of drug content for each tablet of brand A.

\begin{tabular}{lcccccccccc}
\hline \multicolumn{1}{c}{ Tablet no } & 1 & 2 & 3 & 4 & 5 & 6 & 7 & 8 & 9 & 10 \\
\hline $\begin{array}{l}\text { Average weight of each } \\
\text { tablet (mg) }\end{array}$ & 117.2 & 121.4 & 120.3 & 118.9 & 117.7 & 119.4 & 117.1 & 114.2 & 119.3 & 119.0 \\
$\begin{array}{l}\text { Amount of drug in each } \\
\text { tablet(mg) }\end{array}$ & 2.5 & 2.5 & 2.6 & 2.3 & 2.4 & 2.6 & 2.5 & 2.1 & 2.3 & 2.2 \\
\begin{tabular}{l}
$\%$ of content \\
\hline \hline
\end{tabular} & 49 & 50 & 51 & 46 & 48 & 52 & 50 & 43 & 46 & 45 \\
\hline
\end{tabular}

Table. (5). The average weight, amount of drug, and percentage of drug content for each tablet of brand C.

\begin{tabular}{lcccccccccc}
\hline \multicolumn{1}{c}{ Tablet no } & 1 & 2 & 3 & 4 & 5 & 6 & 7 & 8 & 9 & 10 \\
\hline $\begin{array}{l}\text { Average weight of each tablet } \\
\text { (mg) }\end{array}$ & 64.7 & 65.4 & 65.7 & 65.7 & 65.9 & 65.3 & 64.9 & 65.0 & 64.4 & 64.5 \\
$\begin{array}{l}\text { Amount of drug in each tab- } \\
\text { let(mg) }\end{array}$ & 4.0 & 3.8 & 4.0 & 3.7 & 3.9 & 2.9 & 3.3 & 3.4 & 3.2 & 3.5 \\
$\%$ of content & 80 & 77 & 81 & 74 & 78 & 58 & 67 & 67 & 64 & 69 \\
\hline \hline
\end{tabular}

\section{CONCLUSION}

This study showed a significant relationship ( $p$ value $=0.0039$ ) between folic acid consumption and miscarriage. More confirmative quality control tests should be implemented to evaluate the dissolution profile of folic acid tablets. This study emphasized the need for continuous surveillance of folic acid tablets present at Libyan markets by the government to ensure the supply and availability of good quality medicines for the patients in Libya.

Quality measurement shows variation in the active components of the tested folic acid brand names. Concentrations in some folic acid tablets (brand B) were within the acceptable limits of the British pharmacopoeia. Other folic acid tablets (brands A and C) did not comply with the content uniformity test certified in the British pharmacopoeia. This means that these two brands might not give the expected therapeutic effect and might reduce patient compliance.

\section{ACKNOWLEDGEMENT}

The authors are thankful to the following individuals:

- Mr. Aun. O. Younis, for his help with statistical analysis. 
- Mr. Omran Ibrahim for his help with sample preparation.

\section{REFERENCES}

Ahn, E., Nava-Ocampo, A. A., \& Koren, G. (2004). Multivitamin supplements for pregnant women. New insights. Canadian family physician, 50(5), 705706 .

Al-Mashhadane, F. A., Al-Mashhadane, A. A., \& Taqa, A. A. R. (2018). Folic Acid Supplementation: A Review of the Known Advantages and Risks .

Andres, J., Evans, J., \& Royle, C. (2008). Prevalence of congenital anomalies. Canadian Perinatal Health Report, 158-163.

Bower, C., \& Stanley, F. J. (1989). Dietary folate as a risk factor for neural - tube defects: evidence from a case - control study in Western Australia. Medical Journal of Australia, 150(11), 613-619.

Brown, J. E., Jacobs, D. R., Hartman, T. J., Barosso, G. M., Stang, J. S., Gross, M. D., \& Zeuske, M. A. (1997). Predictors of red cell folate level in women attempting pregnancy. Jama, 277(7), 548-552 .

Czeizel, A., Dudás, I., Vereczkey, A., \& Bánhidy, F. (2013). Folate deficiency and folic acid supplementation: the prevention of neural-tube defects and congenital heart defects. Nutrients, $5(11.4775-4760 ،($

Đuriš, J., Čalija, B., Vidović, B., Dobričić, V., Milić, J., \& Ibrić, S. (2017). Comparative analysis of mechanical and dissolution properties of single-and multicomponent folic acid supplements. Journal of Food Composition and Analysis, 60 .24-17 ،
French, A. E., Grant, R., Weitzman, S., Ray, J. G., Vermeulen, M. J., Sung, L., Greenberg, M., \& Koren, G. (2003). Folic acid food fortification is associated with a decline in neuroblastoma. Clinical Pharmacology \& Therapeutics, 74(3), 288-294 .

Goh, Y. I., Bollano, E., Einarson, T. R., \& Koren, G. (2006). Prenatal multivitamin supplementation and rates of congenital anomalies: a meta-analysis. Journal of obstetrics and gynaecology Canada, 28(8), 680-689.

Green, N. S. (2002). Folic acid supplementation and prevention of birth defects. The Journal of nutrition, 132(8), 2356S-2360S .

Hibbard, B. M. (1965). The role of folic acid in pregnancy with particular reference to anaemia, abruption and abortion. Obstetrical \& Gynecological Survey, $20.39-35$ ، (1)

Matias, R., Ribeiro, P., Sarraguça, M., \& Lopes, J. (2014). A UV spectrophotometric method for the determination of folic acid in pharmaceutical tablets and dissolution tests. Analytical Methods, 6(9), 30653071 .

McStay, C., Prescott, S., Bower, C., \& Palmer, D. (2017). Maternal folic acid supplementation during pregnancy and childhood allergic disease outcomes: a question of timing? Nutrients, 9(2), 123 .

Pharmacopoeia, B. (2010). Vol. 1, The Department of Health. British Pharmacopoeia Commission, London, 1,219-222 . 
Pulikkunnel, S. T., \& Thomas, S. (2005). Neural tube defects: pathogenesis and folate metabolism. JAPI, 53, 127-135 .

Ribeiro, M. V. d. M., Melo, I. d. S., Lopes, F. d. C. d. C., \& Moita, G. C. (2016). Development and validation of $\mathrm{a}$ method for the determination of folic acid in different pharmaceutical formulations using derivative spectrophotometry. Brazilian Journal of Pharmaceutical Sciences, 52(4), 741750 .

Smithells, R., Sheppard, S., \& Schorah, C. (1976). Vitamin dificiencies and neural tube defects. Archives of disease in childhood, 51(12), 944-950 .

Smithells, R., Sheppard, S., Schorah, C., Seller, M., Nevin, N., Harris, R., Read, A., \& Fielding, D. (1980). Possible prevention of neural-tube defects by periconceptional vitamin supplementation. The Lancet, 315(8164), 339-340 .

Wald, N., Law, M., Morris, J., \& Wald, D. (2001). Quantifying the effect of folic acid. The Lancet, 358(9298), 20692073 . 
تأثير تناول الحمض الفوليكي على التشوهات الجنينية وحالات الإجهاض وتحليل وحدة مكونات الجرعة لثلاث علامات تجارية للحمض الفوليكي على شكل اقراص

\author{
عادل بالقاسم محمد1*3، عازة منبي علي²، سامية الصاوي مجيد \\ 1 قسم الأمراض، كلبة الطب البيطري، جامعة عمر الدختار، البيضاء. لبييا. \\ 2ق قسم الصبيلانيات والصناعات الصبيلانية، كلبة الصبيلة، جامعة عمر المختار، البيضاء، لبييا.
}

تاريخ الاستلام: 04 مايو 2019 / تاريخ القبول: 30 ديسمبر 2019 https://doi.org/10.54172/mjsc.v34i4.147:Doi

المستخلص: لوحظ مؤخراً ازدياد عدد حالات التشوهات في المواليد. وهذا قد برجع سببه لنقص في حمض الفوليك. حمض الفوليك كمضاد للأكسدة، هو عامل مهم في الوقاية من التشوهات أثثاء مرحلة تطور الجنين. من خلال التحقق من التاريخ الطبي للحالات وقياس وحدة الجرعة، هدفت هذه الدراسة الى فحص دور حمض الفوليك قبل واثتاء الحمل وكذلك للتحقق من محتويات ووحدة الجرعة في الأصناف التجارية المتوفرة من الحمض الفوليكي. الدراسة الاحصائية هدفت الى تحديد العلاقة بين استهلاك حمض الفوليك وحسالات الاجهاض والتشـوهات الجنينيـة في المواليد. قامت الدراسـة بفحص عينـة من 300 إمرأة اعتمـادا على بيانـات

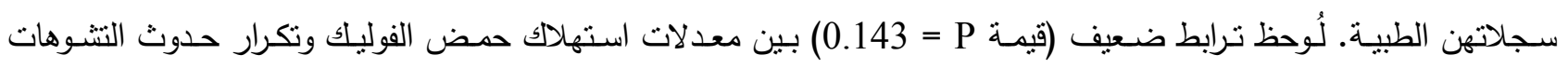

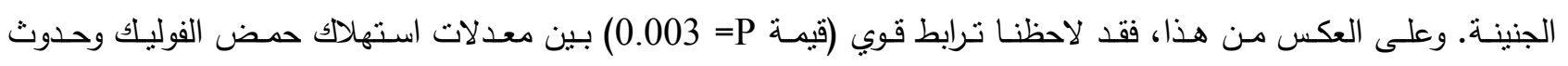
الإجهاض. هذا الترابط، خاصة مع معدلات الإجهاض، يتماشى مع دراسات سابقة ويعطي أهمية لتتاول حمض الفوليك قبل وأثناء الحمل. تم قياس محتويات ووحدة الجرعة لثلاث علامات تجاريـة معروفة لحمض الفوليك (Folic Acid-Nile) و - Folicum

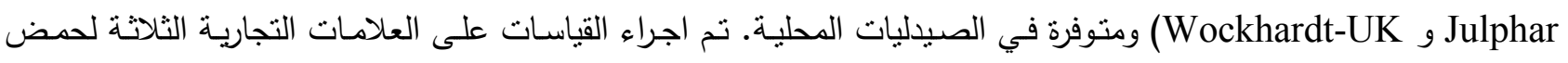
الفوليك وفقا لاختبار توحيد المحتوى لدستور الادوية البريطاني (2010) British Pharmacopoeia (BP) تم اختبار عشرة أقراص من كل علامـة تجاريـة باستخدام طريقة جهاز UV Spectrophotometric. أنشارت النتائج إلى أن العلامـة التجاريـة

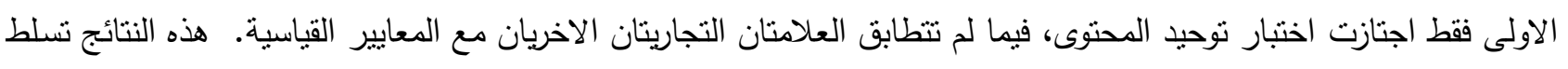

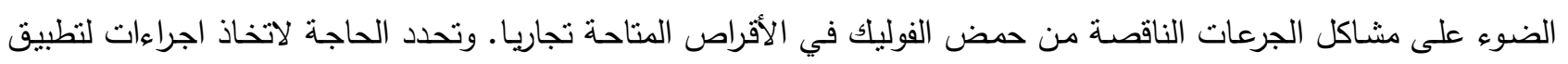
الرقابة على جودة جميع الادوية الطبية.

الكلمات المفتاحية: حمض الفوليك. مضاد الأكسد. نشوهات حديثي الولادة. الإجهاض. 